International Journal of Life Sciences
Available online at http://sciencescholar.us/journal/index.php/ijls
Vol. 2 No. 2, August 2018, pages: $30 \sim 41$
e-ISSN: 2550-6986, p-ISSN: 2550-6994
http://dx.doi.org/10.29332/ijls.v2n2.134

\title{
Pollution with Saprobic Index and Nutrition Value Coefficient of Fish
}

\author{
Sang Ayu Made Putri Suryani a, I Wayan Arya ${ }^{b}$, I Made Suparta ${ }^{c}$ \\ Article history: Received 10 December 2017, Accepted in revised form 20 March 2018, Approved 10 June 2018, \\ Available online 25 June 2018
}

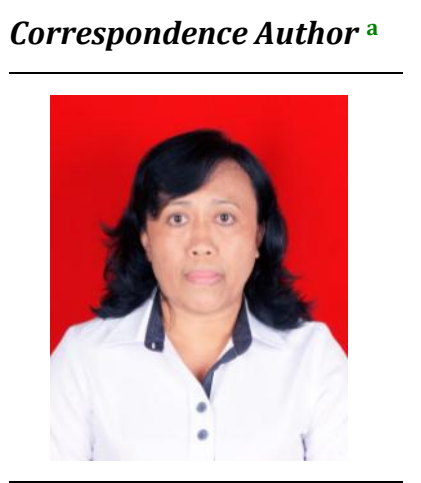

Keywords

Buyan Lake;

Nutritional status;

$N V C$;

Saprobic index;

Value coefficient;

\begin{abstract}
Buyan Lake located in the village of Pancasari, District Sukasada, Buleleng, Bali. Lake area of 301.84 hectares located at an altitude of about 1,000 meters above sea level is one of three twin lake that forms in a large caldera. Buyan Lake is flanked by two other lakes, namely Lake Tamblingan in the west and Lake Beratan in the east. Depth Buyan alone is estimated at around 80 meters, where the depth of the lake is never reached 140 meters before the bottom of the lake due to the silting of Buyan Lake erosion. Water resource who physically looks have undergone significant environmental stress due to things like the level of the lake by the plant closure especially Eichhornia crassipes plants and other aquatic plants, Chlorophyta class consisting of 4 species, Cyanophyta class consisting of six species, one species. Pyrrophyta class at Buyan Lake has included the category of lightly polluted with saprobic coefficient ranges from 0.594 to 0.777 which is well within the range of $\beta$-mesosaprobic saprobic phase. The results of the analysis of nutritional status (NVC) fish that include tilapia, fish Zebra, and Fish Nilem are as follows: Tilapia value status is nutrient is an average of 1,944 which shows the waters of Buyan Lake is still classified as clean fish Zebra average of 1.828, which means the waters Buyan Lake is still in the net category. Fish Nilem to the average value of nutritional status (NVC) is 1.376 which shows the deep waters contaminated state. At each station showed a different saprobic coefficient, the difference is still in a phase of $\beta$-mesosaprobic.
\end{abstract}

e-ISSN: 2550-6986, p-ISSN: 2550-6994@ Copyright 2018. The Author. SS Journals Published by Universidad Técnica de Manabí. This is an open-access article under the CC BY-SA 4.0 license (https://creativecommons.org/licenses/by-sa/4.0/) All rights reserved.

a Water Resource Management Department Warmadewa University Denpasar Bali, Indonesia

b Water Resource Management Department Warmadewa University Denpasar Bali, Indonesia

c Water Resource Management Department Warmadewa University Denpasar Bali, Indonesia 


\section{Contents}

Abstract

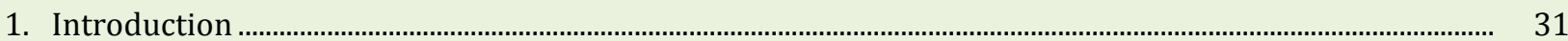

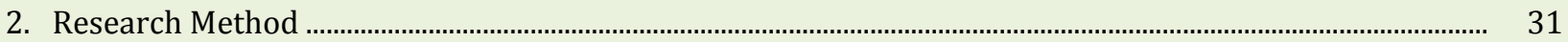

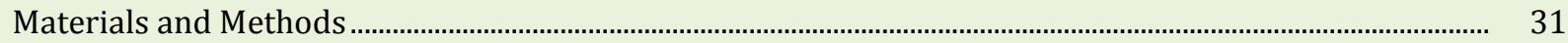

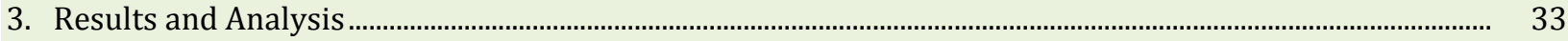

3.1 Saprobic coefficient of Phytoplankton in Buyan Lake....................................................................................... 34

3.2 NVC (Nutrition Value Coefficient) ......................................................................................................................... 36

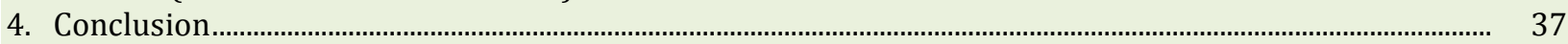

Conflict of interest statement and funding sources......................................................................................... 38

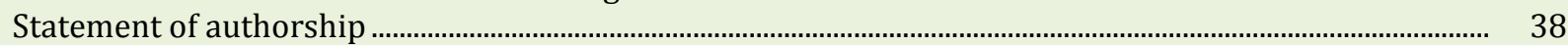

Acknowledgements.................................................................................................................................................... 38

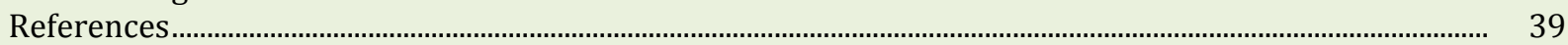

Biography of Authors ............................................................................................................................. 41

\section{Introduction}

Buyan Lake Ecosystem that physically has experienced the pressure of ecological as the closing level of the lake by water plants, especially Eichhornia crassipes plant, a reduction in the extent of the lake because of silting and land conversion in the border lakes, intrusion ingredients of agricultural waste such as fertilizers, pesticides and solids suspended due to leaching of agricultural land around the lake, especially during the rainy season. All these processes will provide ecological pressure and increased pollution in the waters of the lake which affect the presence of phytoplankton as primary producers that will affect the existence and condition of the fish. Fish is one of the ultimate consumer organisms in the aquatic ecosystem of the lake.

Pollution of the lake can affect the dynamic relationships in the ecosystem of the lake involving several compounds, namely from the aspect of the trophic level/food chain level and aspects of life. From the aspect of food chain level, the ecosystem consists of components autotrophic and heterotrophic components, the emphasis on the level of energy transfer. While aspects of life, the ecosystem consists of components biotic and abiotic components that are closely linked and have a reciprocal relationship with one another (Gumilar, 2005).

Agricultural activities that use various types of organic and inorganic fertilizers, as well as a variety of drugs for combating pests in the end slowly in soil residuals will be washed into the lake. In addition, domestic activities and other activities on the lake also contribute to the pollution of the lake and provide ecological pressure on the lake (Gumilar, 2005).

Lake as a freshwater ecosystem has a very important role for human life, therefore the lake needs special attention in order to balance ecosystem management and conservation of the lake can still be maintained. Therefore the management of the lake should be integrated better management of the resources of the lake itself, which includes physical and ecological management and environmental management outside the lake or in the suburban areas of the lake. During this time the management of the lake is more emphasis on the physical management, while biological factors (biotic components) have often been ignored whereas in which there are a variety of aquatic communities ranging from the surface to the seabed (Hadisusanto, 2007).

\section{Research Methods}

\section{Materials and Methods}

This study was conducted in Buyan Lake located in the village Pancasari, District Sukasada, Buleleng. For three weeks, from 20 October until 11 November 2017. At the moment, where is the beginning of the rainy season, the lake began to experience revenue from land waste carried by rainwater flows, while at this time also being dredged the edges of the lake to reduce plant populations air. Sedimentation research begins to conduct a preliminary survey to see the last condition of the lake as well as to determine the location of the sampling stations in Buyan Lake in this case the sampling points are divided into four points, namely on the north, east, south and west which is determined based on consideration of several things:

Suryani, S., Arya, I., \& Suparta, I. (2018). Pollution with saprobic index and nutrition value coefficient of fish. International Journal Of Life Sciences (IJLS), 2(2), 30-41. doi:10.29332/ijls.v2n2.134 
a) Station I in the north to the outskirts of the forest and a lake for farmland

b) Station II on the east side with the edges of agricultural land and agricultural activities and settlements

c) Station III on the south side with the edges of agricultural areas, and population and a small portion for tourism accommodation.

d) Station IV on the west side with the edges of protected forest areas and tourism.

Map of sampling sites

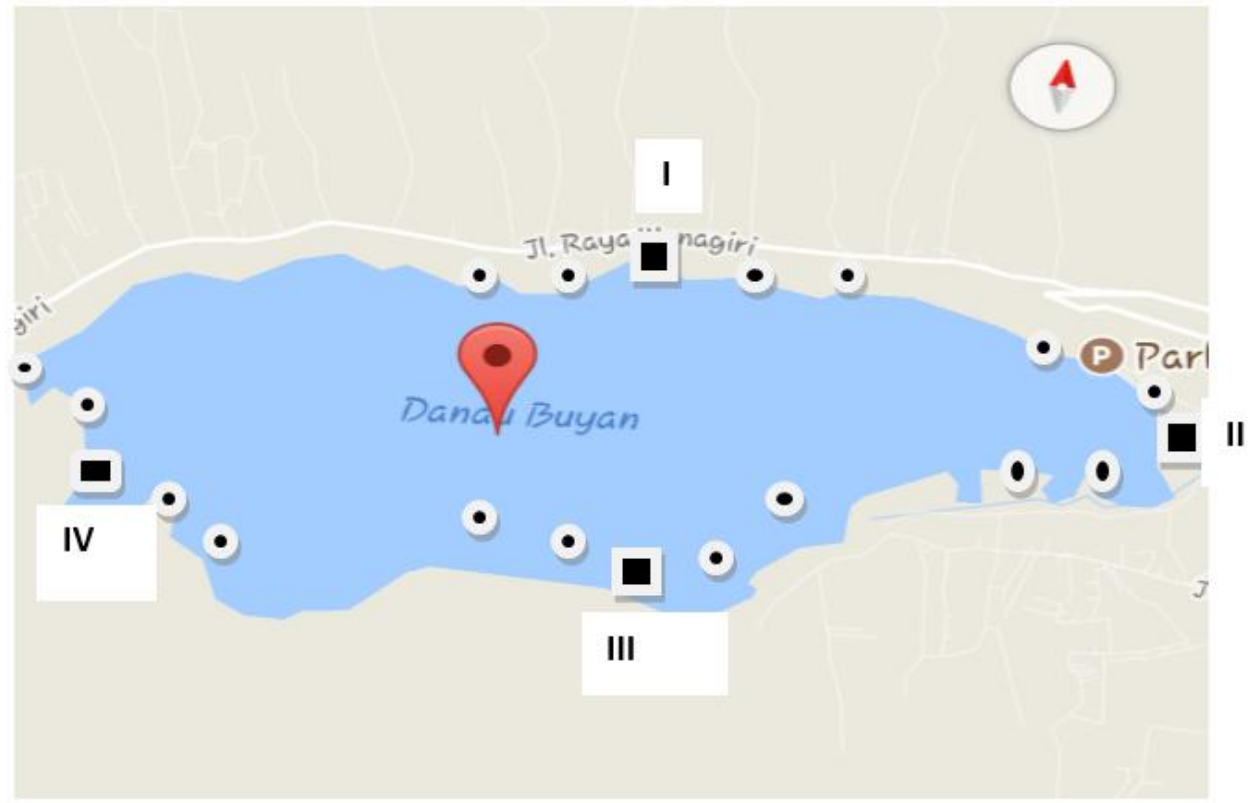

Picture 1. Map of sampling stations

Caption

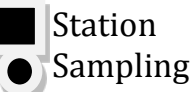

Sampling of phytoplankton in the field is done by taking water samples at each station as much as 20 liters were taken at several different points in order to represent the region of the station, then filtered using a plankton net to obtain a sample volume of $100 \mathrm{ml}$, the sample accommodated in the sample bottle, then given a further sign that the station number given $1 \mathrm{ml}$ Lugol preservatives. This is done in all the stations so that the overall collected 4 sample bottles. Furthermore, the four samples provided the preservative was observed under a microscope to identify the types of phytoplankton contained therein.

Observation under a microscope to do with magnification $100 \mathrm{x}$ and $400 \mathrm{x}$, with three replicates of each sample at one station and five spacious paddocks at each sample was observed. Each specimen of phytoplankton found then photographed with a digital camera and be identified with the help of plankton identification book.

The types of phytoplankton found tabulated in the table and are grouped in the same classes. In addition to tabulating type also noted the average number of specimens per type of class that will be used to calculate the coefficient of saprobic phytoplankton as one of the parameters determining the level of pollution of the lake, especially organic contamination using the formula Drescher and Van der Mark 1976, as follows: 


$$
X=\frac{C+3 D-B-3 A}{A+B+C+D}
$$

Information :

$X=$ coefficient of saprobic, ranging from -3 (Polisaprobic) to +3 (Oligosaprobic)

$\mathrm{A}, \mathrm{B}, \mathrm{C}$ and $\mathrm{D}=$ number of different species in each group saprobic.

$\mathrm{A}=\quad$ Phytoplankton classes that are found belong to class Polysaprobic.

$\mathrm{B}=\quad$ Phytoplankton discovered class into $\alpha$-mesosaprobic class.

$\mathrm{C}=\quad$ Phytoplankton are found into $\beta$-mesosaprobic class.

$\mathrm{D}=\quad$ Phytoplankton classes that are found belong to class Olygosaprobic.

If the value of $\mathrm{x}$ in the above has been obtained, then the way interpretation the level of contamination is by reading the following table:

Table 1

Interpretation of the level of pollution

\begin{tabular}{lcll}
\hline \multicolumn{1}{c}{$\begin{array}{c}\text { Pollutants } \\
\text { Materials }\end{array}$} & Pollutants Level & \multicolumn{1}{c}{ Saprobitic Phase } & \multicolumn{1}{c}{$\begin{array}{c}\text { Saprobic } \\
\text { Coefficient }\end{array}$} \\
\hline Organic Material & Very heavy & $\begin{array}{l}\text { Polisaprobic } \\
\text { Poly / -mesosaprobic }\end{array}$ & $(-3)-(-2)$ \\
& & $\alpha-2)-(-1.5)$ \\
& Quite heavy & $\alpha$-meso / polisaprobic & $(-1.5)-(-1)$ \\
& & $\alpha$-mesosaprobic & $(-1)-(0.5)$ \\
Organic and & Moderate & $\alpha / \beta$-mesosaprobic & $(-0.5)-(0)$ \\
inorganic material & & $\beta / \alpha$-mesosaprobic & $(0)-(0.5)$ \\
& \multirow{2}{*}{ Light } & $\beta$-mesosaprobic & $(0.5)-(1.0)$ \\
& & $\beta$-meso / oligosaprobic & $(1.0)-(1.5)$ \\
Organic and & \multirow{2}{*}{ Very Mild } & Oligo / $\beta$ - mesosaprobic & $(1.5)-(2)$ \\
inorganic material & & Oligosaprobic & $(2.0)-(3.0)$ \\
\hline
\end{tabular}

Source: Awaludin et al, 2015

Besides phytoplankton to determine the level of water pollution as bio-indicators, also used some types of fish are a relatively large presence in Buyan Lake, namely Tilapia fish (Oreochromis niloticus), Zebrafish (Brachidanio rerio), and Nilem Fish (Osthyotilus haselti). The fish is most commonly used as a target for anglers or fishing in Buyan Lake.

Sampling fish only in the third-week study conducted in conjunction with third phytoplankton sampling. Samples of fish used as well as bio-indicators of organic pollution in fish nutrition status and condition factor. To obtain these values is done by measuring the length and weight of the fish is done directly in place of sampling to avoid weight loss of fish due to stress. Furthermore, the length and weight of the value are inserted into the formula NVC (Nutrition Value Coefficient) and fish condition factor with the following formula:

$$
\mathrm{NVC}=\frac{\text { Weight }(\mathrm{g}) \times 100}{(\text { Length })^{3}}
$$

With criteria NVC value is as follows:
$>1.70$
Aquatic Net
$1.30-1.69$
Contaminated waters
0.90 to 1.29
Polluted waters a light
0.50 to 0.89
Being polluted waters
$<0.49$
Heavy polluted waters

Suryani, S., Arya, I., \& Suparta, I. (2018). Pollution with saprobic index and nutrition value coefficient of fish. International Journal Of Life Sciences (IJLS), 2(2), 30-41. 


\section{Results and Analysis}

Observations diversity of phytoplankton are carried out by isolating the phytoplankton in the littoral area of the Buyan Lake with a net plankton and observation under a microscope with a magnification of 400X, overall found five classes of phytoplankton that is class diatoms consisting of two species namely: Epithesia argus and Nitzchia closterium, Desmideacae class consisting of one species namely, Closterium, Chlorophyta class comprising of four species, namely: Ankistrodesmus sp, Lagerhcania chodati, Platidosnima sp, Actinasirun hantzschii, Cyanophyta class consisting of six species, namely: Tricodesnium crythreum, Lyngbya spirulinoidea, Oscillatoria sanota, Microcystus flosaqua, Anabacnopsis raciborskii, Calothrix sp, Pyrrophyta class 1 species namely: Gonyaulax cantenata.

Amount of phytoplankton that is found relatively small, this is caused by at least the penetration of sunlight into the water as a result of the dense canopy or closure of surface water by aquatic plants, especially in areas that have not held the dredging that is on the north side of the lake or the station I and the west side lake or station IV, while the east side is the station south station II and III is being held so that the dredging process rather murky water as a result not many phytoplankton classes that could go on in an atmosphere of lack of sunlight. Phytoplankton in absolute life requires sunlight, but each class needs to sunlight intensity varies (Sachlan, 1982).

Something unusual going on here where the freshwater phytoplankton usually dominated by Chlorophyta class, but in the Buyan Lake is dominated by Cyanophyta class, it is probably more Cyanopyta class can withstand the environmental conditions depressed. Another possibility Cyanopita classes more efficiently utilize sunlight, it can adaptation on competition of the narrow space. According Sachlan (1982) to be able to see the good and the bad situation of the lake waters can be seen from the presence of primary producers, which acts as the main primary producers in the waters of the lake is the phytoplankton of the class Chlorophyta. But the fact indicated by the data above where Chlorophyta class is no longer a dominant plankton in the Buyan Lake would indicate that undergo structural changes phytoplankton population of freshwater normal rules, it can be used as an indication of impairment of water quality in terms of bio-aquatic ecosystems and primary producers that will have a direct impact on the food chain and physical and chemical quality of water.

In terms of compiler structure phytoplankton populations in Buyan Lake class Cyanophyta a constituent of the most dominant in the number of species at most, it shows that the waters of Buyan Lake have experienced the pressure of ecological as class Cyanophyta is the class of phytoplankton belonging to a type of plankton that is quite tolerant of water contaminated or are $\boldsymbol{\alpha}$-Mesosaprobic (polluted) to polysaprobic (heavily polluted). Diatoms are phytoplankton class that has properties similar to saprobity Cyanophyta because both have a wide tolerance and high resistance to organic pollution, especially water pollution (Nawawi, 2013).

Diatomite is microalgae more likely to be clues to the chemical compounds that are toxic in water bodies is the type often found in contaminated waters, this indicates the adaptability of the species. This species is a species that is able to withstand adverse environmental conditions. Pyrophyta also classified as phytoplankton are very tolerant and can survive in waters heavily polluted or are polysaprobic, but the results of this study amount found very little and this is because there are other factors that do not support the growth of the population of its kind, for example, adequacy of nutrient or ingredient less, as is usually the type of phytoplankton blooming in waters undergo eutrophication (excessive enrichment).

From the data of phytoplankton were identified Desmideacae class is a group of phytoplankton that are $\beta$ Mesosaprobik (lightly polluted), where this kind of life good at clean up polluted waters lightweight organic materials. Chlorophyta is a class of phytoplankton that are or tolerance with near Desmideacea pollution, which tends to live in clean waters olygosprobic until lightly polluted. Namawi (2013) states olygosprobic classification reflects the quality of water (associated with uncontaminated waters) that describes the mineralization process is going well and normal oxygen content and phytoplankton dominated by Desmidiaceae and Chlorophyceae.

\subsection{Saprobic coefficient of Phytoplankton in Buyan Lake}

To measure the level of pollution of the waters, in this case, the phytoplankton lake can be used as bioindicator. According to Nawawi (2013), number and arrangement of organisms in the water are highly correlated with the level of water pollution. Some phytoplankton, such as diatoms and dinoflagellates, and zooplankton from the group rotifers, are susceptible to pollutants that its presence in water indicates the water 
conditions. Instead of the existence of protozoan parasites and coliform bacteria in water indicates the water pollution has occurred. Saprobic waters are used to determine the state of water quality resulting from the addition of organic material in a water that is usually the indicator is the number and composition of species of organisms in these waters. Plankton can be used as bioindicators of water because it has a high level of sensitivity to the presence of contamination. (Awaludin, et al, 2015)

Having obtained the types of phytoplankton are grouped by grade and his species, then the waters saprobic coefficient calculation using the formula Drescher and Van der Mark in 1976, the results are presented in Table 2.

Table 2

Saprobic index score per each station

\begin{tabular}{|c|c|c|c|c|c|}
\hline Station & 1 & 2 & 3 & Average & Saprobic Phase \\
\hline I & 0.586 & 0.68 & 0.629 & 0.631 & $\beta$-mesosaprobic \\
\hline II & 0.571 & 0.583 & 0.629 & 0.594 & $\beta$-mesosaprobic \\
\hline III & 0.692 & 0.538 & 0.619 & 0.616 & $\beta$-mesosaprobic \\
\hline IV & 0.703 & 0.857 & 0.777 & 0.779 & $\beta$-mesosaprobic \\
\hline
\end{tabular}

From the table above shows that the average coefficient of saprobic on each station ranged from 0.594 to 0.777 , which indicates a phase value saprobic waters of Buyan Lake is located in the $\beta$-phase which means the waters mesosaprobic still contaminated organic material in the lightweight category. The saprobic coefficient value that describes the relationship with the water pollution level range saprobic coefficient values consisting of five levels presented in Table 2. Based on the table above illustrates that the waters of Buyan Lake have been polluted in the category of lightly polluted, pollutants consisting of organic and inorganic materials. Contamination of organic materials is low can also be seen on the physical condition of the water is still quite clear, odorless and does not seem high suspended solids.

According to Sahabuddin (2012), Materials and wastewater discharges from industrial activities in the form of inorganic and organic materials are often soluble in water. If the waste material from the wastewater soluble and degrade the waste material in the wastewater can cause water discoloration. The smell arising from microbial activity in water remodel organic waste material, especially the group of proteins, are biodegraded into volatiles and smelling (Sahabuddin, 2012).

Low levels of pollution in the waters of Buyan Lake during the study may also be caused during the implementation of the research is still in the category of dry season until the beginning of the rainy season, so the flow of water from the land into the lake is still relatively low, where the source of the pollution of the lake more derived from activities outside good lake from agricultural activities and from household activities. Organic pollution in Buyan Lake is more going on because the flow of water from the lake to the mainland in particular by rainwater that brings agricultural wastes and soil erosion surface brings many suspended solids for example from the soil surface erosion and the remnants of organic fertilizer. At the time of this study little happens because it is still dry season and the beginning of the rainy season.

At the lake conditions like this then the saprobic system is one good way to give an idea of the level of contamination of the lake measured by the biological parameters or bio-indicator as it can provide a picture of the lake in a vulnerable relatively long time and is not an instantaneous parameter.

The saprobic system is the oldest system used to detect water pollution from organic materials. Saprobes describe water quality associated with the organic matter content and composition of organisms in the water. Community life varies by time and place of his life. In this system, an organism can act as an indicator and characterize itself. Saprobic system waters based on a zoning different experience enrichment of organic material which is characterized by plants (algae) and animals (benthic) specifically (Awaludin, Goddess \& Ngabekti, 2015),

While overall phase saprobic waters of Buyan Lake included in the category of $\beta$-mesosaprobic, but when viewed from the average value of the phase saprobity at each station shows the difference, which at the station I representing the north side of the lake has a value of 0.631 is almost close to each with station III, it demonstrates the ecological condition of the lake is relatively similar to where the outskirts of the lake is almost the same that is partly protected forests, agricultural areas, residential, and tourist activities, From this it can

Suryani, S., Arya, I., \& Suparta, I. (2018). Pollution with saprobic index and nutrition value coefficient of fish. International Journal Of Life Sciences (IJLS), 2(2), 30-41. doi:10.29332/ijls.v2n2.134 
be stated in two stations are likely lakes get the same thing, especially pollutants sources, while activity in the lake itself is almost the same. Station II representing the eastern region of the lake shows saprobic coefficient values 0.594 which means that the organic and inorganic contamination east side relative higher than other stations, this is caused by the border regions and the mainland in the east is dominated by agricultural activities and the little settlement. Agricultural activities contribute pollutants of both organic and inorganic highest, given that agricultural activities here are agriculture horticulture, where the use of fertilizers both organic fertilizers and chemical fertilizers is high enough so that it is possible residues of these materials in the soil and slowly carried by water either rain or watering plants water into the lake. In agricultural areas are highly susceptible to erosion or erosion of the soil surface that affect the increase of suspended solids into the lake. Horticulture farmland tends to very loose, plus the use of organic fertilizers, while the soil surface without canopy or permanent closure so it is easily eroded by rainwater or drainage or water plant watering, especially during the dry season or drought. It would be very unlike the case with agricultural-forestry or plantation where abrasion/erosion of surface soil less and soil tends to be more stable.

According to Widodo (2008), the Agricultural activity can cause water pollution mainly due to the use of fertilizers, pesticides, and herbicides. The pollution can poison water organisms, such as plankton, fish, animals that drink the water, and also people who use the water for their daily needs. Residues of pesticides such as DDT accumulates in fish and other organisms can be carried in the food chain to higher trophic levels. Besides the entry of agricultural fertilizer, garbage and dirt to the dam, the lake, and the sea can cause increased organic substances in water. Such improvements result in disruption or water hyacinth growth becomes rapid (blooming). The growth of algae or hyacinth that can quickly lead to more death and decomposition. The process requires dissolved oxygen, resulting in lower levels of dissolved oxygen in the water. These conditions encourage the growth of anaerobic organisms in the water. This phenomenon is also known as eutrophication. Furthermore, it also mentioned solid waste material, as well as the sources of pollution for the purposes of solid waste material, is a material which is solid, whether rough or smooth, such as garbage. The wastewater disposal to be pollution and would lead to the dissolution, precipitation or colloidal formation. If the solid waste material is causing dissolution, then the density or specific gravity of water is going up. This dissolution is sometimes accompanied by changes in watercolor. Water containing a concentrated solution and the dark will reduce the penetration of sunlight into the water. So that the process of photosynthesis of plants in the water will be disrupted. The amount of dissolved oxygen in water is reduced, the life of organisms in the water are also affected. The occurrence of sediment in the bottom waters will greatly disrupt the life of organisms in the water because sediment would cover the bottom surface water that may contain fish eggs that can not hatch. In addition, the sediment can also hinder a source of food fish in the water and block the sunlight. The formation of colloidal occurs when the exhaust finely shaped so that some have dissolved and some others hover so the water becomes cloudy. Turbidity also impedes the penetration of sunlight, thereby inhibiting photosynthesis and reduced levels of oxygen in the water (Widodo, 2008). so some have dissolved and some others hover so the water becomes cloudy. Turbidity also impedes the penetration of sunlight, thereby inhibiting photosynthesis and reduced levels of oxygen in the water (Widodo, 2008). so some have dissolved and some others hover so the water becomes cloudy. Turbidity also impedes the penetration of sunlight, thereby inhibiting photosynthesis and reduced levels of oxygen in the water (Widodo, 2008).

\subsection{NVC (Nutrition Value Coefficient)}

In this study, in addition to using bio-indicators of phytoplankton also analyze several types of fish in Buyan Lake that includes nutritional status or fish NVC and condition factor. Types of fish sampled as bioindicators are the kind of Tilapia fish (Oreochromis niloticus), Zebrafish (Tilapia buttikoferi), and Nilem Fish (Osteochilus hasselti). Aquatic organisms, especially fish are bio-indicators of water pollution is best. Structural abnormalities, functional and weight of fish as a result of biological water pollution can be observed by counting Nutrition Value Coefficient (NVC) fish in these waters.

The results of the analysis of NVC for tilapia from 25 fish samples showed that the lows are 1.274 and the highest is 2.915 which shows that the condition of the waters of the lake ranges from category contaminated to clean, but the average value of NVC fish is 1.944 which shows the waters of Buyan Lake still classified as clean. From the analysis of NVC tilapia provide information that the waters of Buyan Lake are still classified in the category of the net. Net is meant here is clean to the category of public waters, the water category is class 2 . 
Based on Government Regulation No. 82 of 2001, Article 8 of Environmental Management, classification and criteria for water quality set into 4 classes: Class 1 : water that can be used as raw material for drinking water or other uses require water quality are the same, Class 2: water that can be used for infrastructure / facilities water recreation, freshwater fish farming, animal husbandry, and agriculture, Class 3: water that can be used for freshwater fish farming, livestock and agriculture, Class 4: water that can be used to irrigate crops / agriculture.

The analysis result NVC Zebrafish (Tilapia buttikoferi) shows that not too much different from Tilapia fish with a value of NVC lowest was 1.457 and the highest is 2.343 , which depicts the waters in the category of contaminated until it is clean, but the average value NVCnya is 1.828, which means Buyan lake waters are still in the net category.

Things are a little different is the result of the analysis of fish NVC Nilem (Osteochilus hasselti), Where the value of NVC was relatively lower than the Tilapia and Zebrafish. NVC tilapia fish Nilem ranged from 1.047 to 2.048. Of the 25 fish samples showed only one tail in the category of clean water and the remaining shows in the category of contaminated waters. On the average value of NVC fish, Nilem is 1.376 which shows the state of contaminated wastewaters in both organic and inorganic waste.

NVC value differences Nilem with Tilapia fish and fish Zebrafish due Nilem tolerance against contaminants much lower or fish more sensitive, so the conditions were little-disturbed water had an impact on the physical and metabolism. Of the three types of fish analyzed its NVC then Nilem fish is best used as bioindicators of polluting the waters for fish Nilem very sensitive to changes in the marine environment and to their inputs contaminants.

Condition Factor of fish that express the degree of fish health in the physical that includes morphological and physiological fish is calculated in the same manner as calculating the NVC to look at the relationship the weight and length of the fish, the only difference with the NVC is in terms of the criteria, which in condition factor is often symbolized by "R" only expressed the fish are healthy or unhealthy. According to Sutjiati (1990) that when the value of condition factor (R) is greater than or equal to 1.7 signifies a fish in a healthy state, if less than 1.7 means the fish are less healthy, and if the R-value is less than 1.3 fish is very unhealthy,

Referring to the value NVC when used to determine the health of the fish, then for Tilapia with an average value is 1.944 declared Tilapia fish that live in the Buyan Lake categorized as healthy, as well as Zebrafish with an average value 1.828 means that also in the category of healthy, for Nilem fish value just below 1.7 with an average of 1,376 which means Nilem fish condition factor in an unhealthy state. Conditions Nilem unhealthy fish here also cannot be separated from power tolerance Nilem fish against contamination of materials and low environmental changes. Nilem fish with low-level health is inseparable from the waters of Buyan Lake conditions that have experienced contamination and at the time of the research is a transition season or the end of the dry season and into the beginning of the rainy season, causing changes in extreme environments from time to time. This allows Nilem fish health is not good, but on the same token Nilem fish illustrates that there has been a change on aquatic ecosystems, one of which has occurred pollution, both organic and inorganic contamination.

Of the two components, namely bio-indicators of phytoplankton with saprobic coefficient and fish with nutritional status or NVC and condition factor, it can be stated that the waters of Buyan Lake have experienced pollution with pollution categories of contaminated until lightly polluted.

\section{Conclusion}

From these results it can be concluded as follows:

a) The diversity of types of phytoplankton overall found 5 classes of phytoplankton that is class diatoms consisting of 2 species, class Desmideacae consisting of one species, classes Chlorophyta which consists of 4 species, Class Cyanophyta which consists of 6 species, Class Pyrophyta 1 species, meaning Buyan Lake has included the category of lightly polluted with saprobic coefficient ranges from 0.594 to 0.777 which is well within the range of $\beta$-mesosaprobic saprobic phase.

b) The results of the analysis of nutritional status (NVC) fish that include Tilapia fish, Zebra Fish, and Nilem fish are as follows: Tilapia nutritional status is an average of 1.944 which shows the waters of Buyan Lake is still classified as clean. Nutritional status (NVC) Zebra Fish average of 1.828, which means the waters

Suryani, S., Arya, I., \& Suparta, I. (2018). Pollution with saprobic index and nutrition value coefficient of fish. International Journal Of Life Sciences (IJLS), 2(2), 30-41. doi:10.29332/ijls.v2n2.134 
of Buyan Lake is still in the net category. Nilem fish to the average value of nutritional status (NVC) is 1.376 which shows the deep waters contaminated state.

At each station showed the saprobic coefficient of different, but the difference is still in a phase of the same saprobic ie $\beta$-mesosaprobic, indicating lightly polluted waters.

Conflict of interest statement and funding sources

Sang Ayu Made Putri Suryani declared that she has no competing interest. The study was financed by Research Department Warmadewa University

Statement of authorship

Sang Ayu Made Putri Suryani have a responsibility for the conception and design of the study. Sang Ayu Made Putri Suryani have approved the final article.

Acknowledgments

Thank you for Rector Warmadwa University, Deen of Agriculture Faculty to support our study and thank for I Wayan Suryasa for helping our publication. 


\section{References}

1. Abadie, C., Chilin-Charles, Y., Huat, J., Salmon, F., Pignolet, L., Carlier, J., ... \& Jenny, C. (2007, September). New approaches to select cultivars of banana with durable resistance to Mycosphaerella leaf spot diseases. In III International Symposium on Banana: ISHS-ProMusa Symposium on Recent Advances in Banana Crop Protection for Sustainable 828 (pp. 171-178).

View in (Google Scholar)

2. Awaludin, A. S., Dewi, N. K., \& Ngabekti, S. (2015). Koefisien Saprobik Plankton Di Perairan Embung Universitas Negeri Semarang. Jurnal MIPA, 38(2), 115-120.

View in (Google Scholar)

3. Chilán, J. C. H., Torres, S. G. P., Machuca, B. I. F., Cordova, A. J. T., Pérez, C. A. M., \& Gámez, M. R. (2018). Social Impact of Renewable Energy Sources in the Province of Loja. International Journal of Physical Sciences and Engineering (IJPSE), 2(1), 13-25.

View in (Google Scholar)

4. Diposaptono, S., Gumilar, P., Pratikto, W. A., Lt, G. D., \& No, J. M. M. T. (2005, November). Coastal disaster mitigation in Indonesia. In International Symposium Disaster Reduction on Coasts Scientific-SustainableHolistic-Accessible (pp. 14-16).

View in (Google Scholar)

5. Garno, Y. S. (2008). Kualitas air dan dinamika fitoplankton di perairan Pulau Harapan. Jurnal Hidrosfir Indonesia, 3(2), 87-94.

View in (Google Scholar)

6. Islami, M. M. (2015). Distribusi spasial gastropoda dan kaitannya dengan karakteristik lingkungan di pesisir Pulau nusalaut, Maluku tengah. Jurnal Ilmu dan Teknologi Kelautan Tropis, 7(1), 365-378.

View in (Google Scholar)

7. Isnansetyo, A., \& Kurniastuty, E. (1995). Teknik Kultur Phytoplankton dan Zooplankton. Pakan Alami untuk Pembenihan Organisme Laut. Penerbit Kanisius, Yogyakarta.

View in (Google Scholar)

8. Jain, P., Jain, A., Singhai, R., \& Jain, S. (2017). Effect of Biodegradation and Non Degradable Substances in Environment. International Journal of Life Sciences (IJLS), 1(1), 58-64.

View in (Google Scholar)

9. Jurado, W. C. C., Pérez, A. V. P., Quiroz, A. M. V., \& Gámez, M. R. (2017). Environmental Impact On Electrical Networks Near The Manabita Litoral. International Journal of Life Sciences (IJLS), 1(2), 18-27.

View in (Google Scholar)

10. Manu, G., Baroleh, M., \& Kambey, A. D. (2012). Studi Fitoplankton di Danau Tondano Provinsi Sulawesi Utara. Jurnal Perikanan dan Kelautan Tropis, 6(1), 13-17.

View in (Google Scholar)

11. Nemerow, N. L. (1991). Stream, lake, estuary, and ocean pollution.

View in (Google Scholar)

12. Nybakken, J. W., \& Eidman, H. M. (1998). Biologi laut: satu pendekatan ekologis. Gramedia. View in (Google Scholar)

13. Odum, E. P. (1993). Dasar-dasar Ekologi. Edisi Ketiga Penerjemah Ir. Tjahjono Samingan, MSc. View in (Google Scholar)

Suryani, S., Arya, I., \& Suparta, I. (2018). Pollution with saprobic index and nutrition value coefficient of fish. International Journal Of Life Sciences (IJLS), 2(2), 30-41. doi:10.29332/ijls.v2n2.134 
14. Pancho, J. V., \& Soerjani, M. (1978). Aquatic Weeds of Southeast Asia. SEAMEO Regional Center for Tropical Biology (BIOTROP), Bogor, Indonesia.

View in (Google Scholar)

15.Sachlan, M. (1982). Planktonologi. Fakultas Peternakan dan Perikanan Universitas Diponegoro, Semarang, 156.

View in (Google Scholar)

16. Sahabuddin, E. S. (2012). Cemaran air dan tercapainya lingkungan sumber daya alam yang berkelanjutan. Publikasi Pendidikan, 2(2).

View in (Google Scholar)

17. Setyawan, N. (2013). Gambaran Mikroanatomi pada Insang Ikan Sebagai Indikator Pencemaran Logam Berat di Perairan Kaligarang Semarang (Doctoral dissertation, Universitas Negeri Semarang).

View in (Google Scholar)

18. Soeprobowati, T. R., \& Hadisusanto, S. (2009). Diatom dan Paleolimnologi: Studi Komparasi Perjalanan Sejarah Danau Lac Saint-Augustine Quebeq-City, Canada dan Danau Rawa Pening Indonesia. Biota, 14(1), 60-68.

View in (Google Scholar)

19. Takim, R., Harris, M., \& Nawawi, A. H. (2013). Building Information Modeling (BIM): A new paradigm for quality of life within Architectural, Engineering and Construction (AEC) industry. Procedia-Social and Behavioral Sciences, 101, 23-32.

View in (Google Scholar)

20.Widodo, P. (2008). Potensi pencemaran air tanah oleh penggunaan pupuk nitrogen pada tanaman melon di Kecamatan Kebonarum Kabupaten Klaten (Doctoral dissertation, Universitas Muhammadiyah Surakarta). View in (Google Scholar) 


\section{Biography of Authors}

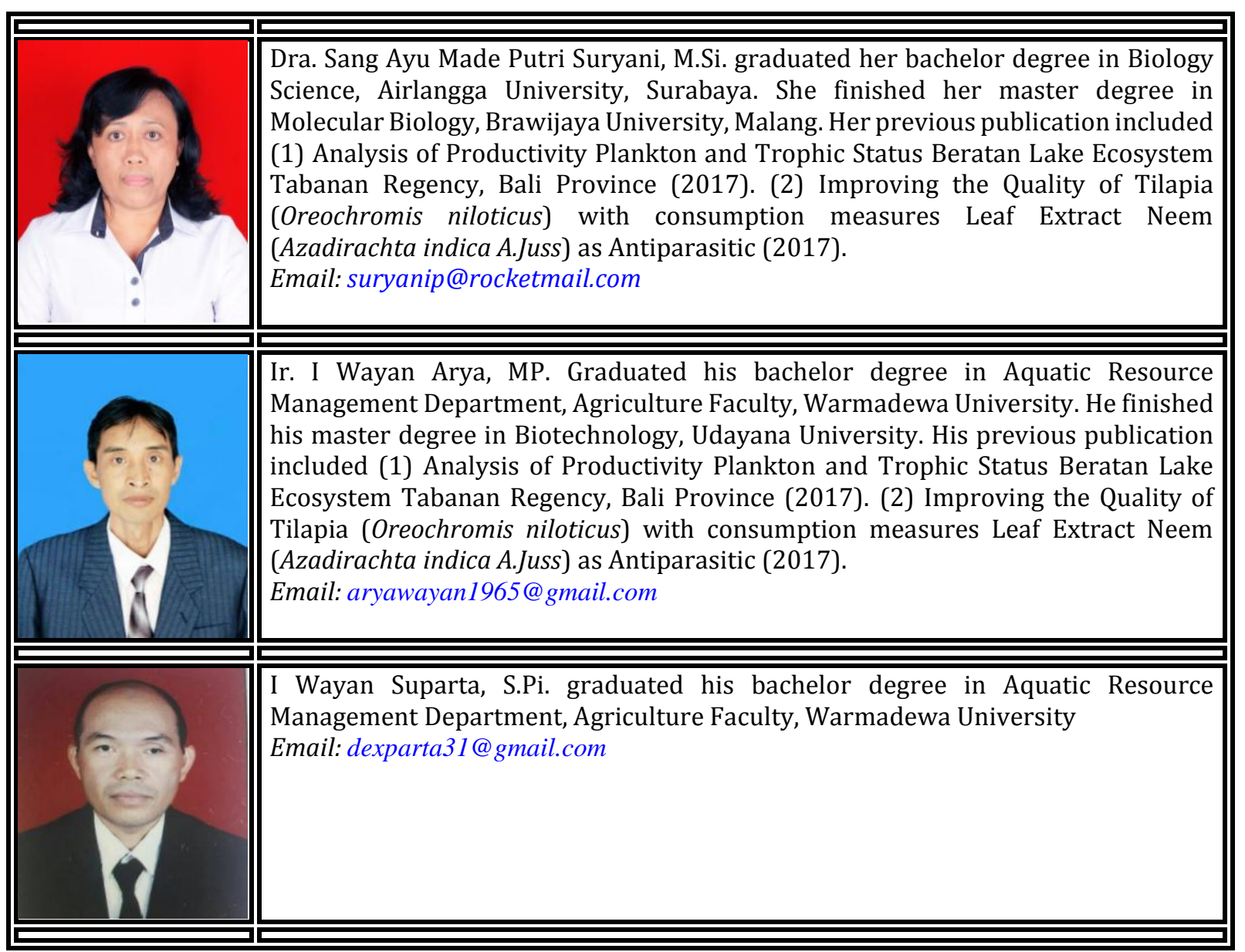

Suryani, S., Arya, I., \& Suparta, I. (2018). Pollution with saprobic index and nutrition value coefficient of fish. International Journal Of Life Sciences (IJLS), 2(2), 30-41. doi:10.29332/ijls.v2n2.134 